Brevik, Eric C., Daniel deB. Richter, Eric P. Verrecchia, John Ryan, Rosa M. Poch, Onn Crouvi, Daniela Sauer, Jaroslaw Waroszewski, Elizabeth Solleiro-Rebolledo, Curtis Monger, Franz Ottner, and Victor Targulian. 2015. The Influence of Dan H. Yaalon: His Impact on People. Catena. in press. doi: 10.1016/j.catena.2015.10.012

\title{
The Influence of Dan H. Yaalon: His Impact on People
}

Eric C. Brevik ${ }^{1 *}$, Daniel deB. Richter ${ }^{2}$, Eric P. Verrecchia ${ }^{3}$, John Ryan ${ }^{4}$, Rosa M. Poch ${ }^{5}$, Onn Crouvi ${ }^{6}$, Daniela Sauer ${ }^{7}$, Jaroslaw Waroszewski ${ }^{8}$, Elizabeth Solleiro-Rebolledo ${ }^{9}$, Curtis Monger ${ }^{10}$, Franz Ottner ${ }^{11}$, and Victor Targulian ${ }^{12}$

1 - Department of Natural Sciences, Dickinson State University, Dickinson, ND, USA.

Eric.Brevik@dickinsonstate.edu

2 - Nicholas School of the Environment, Duke University, Durham, NC, USA. drichter@duke.edu

3 - Institute of Earth Surface Dynamics, Faculty of Geosciences and the Environment, University of Lausanne - CH-1015 Lausanne, Switzerland. Eric.Verrecchia@unil.ch

4 - Consultant Soil Scientist, Carrigataha, Cahir, County Tipperary, Ireland. Formerly Professor of Soil Science, American University of Beirut, Beirut, Lebanon, and latterly Soil Scientist, International Center

For Agricultural Research in the Dry Areas (ICARDA), Aleppo, Syria. ryanjohn1944@gmail.com

5 - Departament de Medi Ambient i Ciències del Sòl, Universitat de Lleida, 25198 Lleida, Spain. rosa.poch@macs.udl.cat

6 - Geological Survey of Israel, Jerusalem, Israel. crouvi@gsi.gov.il 7 - Institute of Geography, University of Göttingen, Göttingen, Germany. Daniela.Sauer@geo.uni-goettingen.de

8 - Wroclaw University of Environmental and Life Sciences, Institute of Soil Science and Environmental Protection, Wroclaw, Poland. jaroslaw.waroszewski@gmail.com

9 - Universidad Nacional Autónoma de México, Mexico City, Mexico. solleiro@geologia.unam.mx

10 - Soil Science Division, USDA-NRCS, Lincoln, NE, and Professor Emeritus, New Mexico State University, Las Cruces, NM, USA. Curtis.Monger@lin.usda.gov

11 - University of Natural Resources and Life Sciences, Vienna, Institute of Applied Geology, Vienna, Austria.franz.ottner@boku.ac.at

12 - Institute of Geography, Russian Academy of Sciences, Moscow, Russia. votargulian@gmail.com

* - corresponding author

\section{Abstract}

There are many ways to measure the accomplishments of a scientist, such as papers and books

published, citations, and prestige of journals published in, but we rarely gather information that allows

us to evaluate the variety of influences that individual scientists have on the careers of others. Dan $\mathrm{H}$.

Yaalon was one of the most accomplished pedologists of the $20^{\text {th }}$ and early $21^{\text {st }}$ centuries. In this paper we gather personal testimonials of the impact Yaalon had on scientists working in the areas of interest to Yaalon. This allows us to qualitatively evaluate the impact of an influential scientist on his field through the ways that he influenced the career choices of others. We found that this influence occurred through 1) personal, face-to-face contact, 2) written correspondence between Yaalon and other scientists, both through letters and through email, and 3) Yaalon's written record itself, without any 
39 direct, personal interaction between Yaalon and the other scientists. This influence took place over

40 multiple generations of scientists, ranging from individuals who are currently retired to those who are

41 just now in the very early stages of their scientific careers. The Yaalon example makes clear how

42 successful scientists make significant contributions to their fields of interest well beyond those indicated

43 by commonly used measures.

45 Keywords: pedology; paleosols; soil science history; aeolian processes; scientific contributions; scientific 46 influence

\section{Introduction}

49 Dan Hardy Yaalon (1924-2014) (Figure 1) was one of the most accomplished pedologists of the $20^{\text {th }}$ and 50 early $21^{\text {st }}$ centuries. Common measures of individual scientific accomplishment include numbers of 51 papers and books written, prestige of journals published in, numbers of citations, and number and

52 financial value of research grants received. By any of these measures Dan Yaalon was highly

53 accomplished. He published over 200 articles and reports, many in leading international journals

54 including BioScience, Catena, Clay Minerals, Earth Sciences History, Geoderma, Global and Planetary

55 Change, Journal of Arid Environments, Journal of Sedimentary Research, Journal of Sedimentary

56 Petrology, Nature, Sedimentary Geology, Soil Science, and Soil Science Society of America Journal

57 (Yaalon, 2012). Yaalon's work was highly respected and cited; according to Google Scholar

58 (http://scholar.google.com/) his works were cited thousands of times giving him an h-index of 38 and an

59 i10-index of 91 (as of 4 July, 2015). Yaalon made significant contributions in several scientific fields,

60 including soil science (particularly the science of pedology), geomorphology, paleosols (Figure 2),

61 environmental reconstruction, and soil science history. Yaalon was a recipient of both the Dokuchaev

62 Medal in 2010 (Itkin, 2014), recognizing major research accomplishments in soil science, and the Sarton 
63 Medal from Ghent University in 2000 (Yaalon, 2000), recognizing excellence in research into the history

64 of science. These awards demonstrate Yaalon's transdisciplinary contributions. Yaalon himself felt that

65 his greatest contributions were in the areas of the influence of dust on pedogenesis and the

66 geomorphology of Israel (Yaalon, 2012).

68 While quantitative measures are appealing to those who think scientifically and are relatively easy to

69 assemble, they have their strengths and weaknesses, and they hardly represent the full measure of

70 Yaalon's impact on his fields of interest. The ways in which Yaalon influenced other scientists are more

71 difficult to quantify, yet can be appreciated in the "in memoriam" pieces written by colleagues and

72 admirers following his death (e.g., Finck, 2014; Itkin, 2014; Richter et al., 2014; Rohdenburg, 2014).

73 Another approach to a non-quantitative evaluation of Yaalon's influence was on display at the

74 international symposium attended by more than 60 participants from 16 separate countries held in

75 Yaalon's honor in Vienna, Austria 8-11 April, 2015. In this paper we have collected testimonials from

76 some of the attendees of that symposium representing multiple scientific generations and from wide

77 geographic distribution. These testimonials provide information on how Yaalon influenced each scientist

78 and allow us to qualitatively evaluate the variety of impacts Yaalon had as a highly influential and

79 accomplished scientist.

80

\section{Mentor of the Young - Eric C. Brevik}

82 One of the subjects that has been an important part of my career is the history of soil science. I was

83 introduced to this as a graduate student at lowa State University when I took a class on soil genesis and

84 survey. My professor (Thomas Fenton) assigned a term paper where each student in the class was to

85 research a person who was important in the history of soil genesis and survey. I was assigned George

86 Nelson Coffey, and I began my research by going to secondary sources. However, I rapidly learned that 
87 while each of these secondary sources stated that Coffey had ideas on soil classification that were ahead

88 of his time, they all had essentially the same three or four sentences of information and nothing more.

89 To write a paper on Coffey I was going to have to delve into his primary works, which I set about doing.

91 By the time I completed my term paper I had far more information on Coffey than I had seen anywhere

92 else, and I decided I should pursue publishing the work. After some revisions the manuscript was

93 accepted by the Soil Science Society of America Journal (Brevik, 1999), making the paper on Coffey my

94 third peer-reviewed article and my first soil science history article. However, publication of the article

95 had been largely serendipitous; I didn't have plans to pursue soil science history any further. Then, a few

96 weeks after publication of the Coffey paper, a letter arrived from Dan Yaalon. I was a graduate student,

97 unknown to almost anyone in the soil science community outside my own university, and I had a letter

98 from Dan Yaalon! He complemented me on the Coffey paper, encouraged me to continue work in the

99 area of soil science history, and going one step farther (a characteristic of Dan's), he suggested another

100 individual, Edward Elway Free, who had been ahead of his time but was largely ignored by the soil

101 science community and deserved to have his history documented. My research on Free also became a

102 published soil science history paper (Brevik, 2004), and I have now published a total of 21 articles to

103 date that are historical or have soil history as a major portion of the paper.

105 I continued to carry on correspondence with Dan until shortly before his death and had one opportunity

106 to meet him in person, at the 2000 Soil Science Society of America (SSSA) meetings in Minneapolis. Dan

107 became a mentor, particularly in the area of soil science history. He continued to make opportunities

108 available to me, doing things such as suggesting my name to editors who were looking for people to

109 write on soil science history, including me as a co-convener in a World Congress of Soil Science

110 symposium on soil science history, and reading materials I was working on to provide suggestions before 
111 the manuscripts were submitted. My involvement in soil science history has also lead to many other

112 professional opportunities within the science of soils (e.g., Brevik and Burgess, 2013; Brevik et al., 2015a;

113 Brevik et al., 2015b) and Dan has continued to inspire soil history projects (Brevik et al., 2015c). I will

114 forever be grateful for the time Dan took to encourage a young graduate student he had yet to actually

115 meet.

116

117 3. My Time with a Giant - Dan Richter

118 I only met Dan Yaalon on the internet. I sent him a question in the early 2000 s and quickly received a

119 thoughtful reply, a reply that also contained what I came to call "a Yaalon critique"! But in addition to

120 his critical stance, he always had a graciousness that invited me to follow up with new emails and I

121 began challenging my graduate students to write to Dan if they had questions about soils. I can only

122 imagine Yaalon's physical state in his latter years. He never got into details but I knew he was at least

123 having difficulties with walking. Yet, he was active at his desk with his many books, papers, and

124 computer. For me, this communication with Yaalon came at a time during which I was educating myself

125 in all aspects of the venerable science of pedology. I had worked to promote long-term soil experiments

126 for several decades, but I felt I needed to better connect field-plot experiments with their larger

127 systems. These conversations with Yaalon, in my opinion one of the greatest of all pedologists, were

128 central to my education.

130 During this time, Dan Yaalon wrote a proposal to create an International Union of Soil Sciences (IUSS)

131 Working Group (WG) on "Global Soil Change." Unable to promote such a proposal on his own (he was

132 approaching 90), Yaalon sent the proposal to Dr. Ahmet Mermut (University of Saskatchewan) and me.

133 We felt pleased and humbled to lend our hands to Yaalon's project. The WG was established, accepted

134 by IUSS, and a companion WG was formed in SSSA. We wrote a paper about the kind of future for soil 
135 science the group envisioned (Richter et al., 2011), a forward-leaning paper we called "Human-soil

136 relations are changing rapidly". The paper had 30 co-authors from many generations, including a

137 number of veteran scientists in addition to Yaalon. Whether or not these WGs have a future as currently

138 constituted is not certain for they are passing to new leadership. Yet, the ideas in the 2011 statement

139 are still very much on the table, many of them directly posed by Dan Yaalon.

140

141 By about 2010, I felt ready to write a pedological essay loosely patterned after a sweeping essay I had

142 read as a graduate student, an essay on the state of the science in the 1960s written by Cornell's long-

143 standing Professor Marlon Cline, a piece he had entitled "The changing model of soil" (Cline, 1961). I

144 thought it important to revisit Cline's objectives fifty years after his summary publication. Yaalon

145 remembered Marlon Cline well. We jointly re-read Cline's essay and I proposed that we jointly write a

146 new paper with three legs to stand on, three themes that would provide a balanced not overly

147 complicated story line about on-going changes in the model of soil. Yaalon was quick and adamant

148 about one of these changes and wrote something like, "since Dokuchaev, the most important change in

149 the model of soil is the idea that most soils are formed by polygenesis and that they contain paleosolic

150 features accumulated over their lifetimes." He shared a 1980s paper of his on reconstructing past

151 environments in which he had clearly made a similar point. In subsequent weeks and months, Yaalon

152 would lead me into a body of literature that I was not yet familiar with, had not yet read, or had not

153 read carefully, papers and books that were so exciting, interesting, and convincing that I became an

154 adherent of soil polygenesis, soils as paleosols, and soil evolution. (In the great soils books of our time,

155 by, for example, Schaetzl, Buol, Targulian, and others, one finds growing recognition for this

156 fundamental and extremely important change in the model of soil). 
158 My suggestion for the second of this three-legged manuscript was the transformation of Earth's soils

159 from natural to human-natural bodies and systems. Ironically, my support letter for Yaalon to be the 160 Dokuchaev Prize winner (2010) had argued that Yaalon himself had been amongst the first to explicitly

161 explore this soil transformation, which fundamentally alters the natural-body concept of soil. Yaalon's

162 paper with Bruno Yaron in 1966 was many decades ahead of its time in outlining how natural soil

163 profiles were increasingly becoming the parent materials for human alteration. Our paper's third leg

164 was the extension of the depth of the soil profile, which was greeted by Yaalon with enthusiasm and had 165 even been foreshadowed as a future change by Cline in his 1961 essay. At our paper's end, which we 166 entitled, "'The Changing Model of Soil' Revisited" (Richter and Yaalon, 2012), we combined the three

167 changes to conclude that human forcings represented a global wave of soil polygenesis altering fluxes of

168 matter and energy and transforming the thermodynamics of soils as potentially very deep systems.

170 During our many emails and the give and take of rewriting, the ever critical Yaalon had once threatened

171 to resign his co-authorship, but in the end we hung together, and it was Yaalon's special graciousness

172 that he left in his wake. He sent me a copy of his autobiography, published in 2012 , and in reading it I

173 have never been so speechless as when I read the Epilogue. There verbatim is our Changing Model

174 paper's abstract, reprinted in full, along with a powerful statement that our paper represented, to Dan

175 Yaalon, the culmination of his life's work. I can only add that I wish that I am able to intellectually and

176 spiritually touch my colleagues and students in some of the ways this great man had touched me.

\section{From Maieutics to Soils - Eric Verrecchia}

179 The first time I was on a field trip with Dan Yaalon, he took me to the kurkar outcrops (carbonate180 cemented aeolianites) in Tel Dor, along the northern coast of Israel. "Do you see all the feldspars?" he 181 asked me, holding out a handful of sand from the beach. Although I looked carefully, I could not really 
182 identify many feldspars. In fact, most of the grains were quartz. "Slicha (sorry in Hebrew), Dan, I

183 don't...." "Well, where do you think all the calcium for cementation is coming from?" It was in 1986, I

184 was 25 years old, and I'm still working on the answer: the coupled calcium-carbon terrestrial cycle.

186 In 1985, I decided to start a PhD on calcretes in Israel. The obvious person to contact was Dan. I sent him

187 a letter without really thinking he would take the time to answer a young French student, but he did,

188 and very quickly. I still have his incredibly nice letter, written with a typewriter. He invited me to visit

189 him and to see what innovations could be possible on this topic. The next summer, I flew to Israel and

190 met Dan for the first time. He told me that he was giving a field course to postgraduate students and

191 invited me to join them. We spent five fantastic days in the Carmel, Galilee, along the Sharon, looking at

192 carbonate soils, paleosols, aeolianites, Vertisols, hamra (red sandy clay loam), and nazaz (red sandy soils

193 with pseudogley). His teaching method was directly inspired from Socrates: maieutics. He did not give

194 me answers, he just responded with other questions, pointing me in the right direction, stimulating me

195 to seek explanations for myself. Of course, at the time, he already knew the importance of the

196 contribution from dust to explain the cycles of elements in the soils of Israel, including along the coast.

198 Dan Yaalon was sort of a grumpy character, but in an amazingly endearing way. It was, I suppose, his

199 way to show his respect. I asked him many times to write letters of recommendation and he always

200 answered positively. In 1995, when I decided to send a paper to Biogeochemistry (Verrecchia and

201 Dumont, 1996), dealing with a biogeochemical model that can be responsible for some carbonate

202 hardening in Israel (in nari), he immediately supported me and acted as a remarkable reviewer.

203 Although we were not in total agreement regarding the genesis of calcrete at Sde Boqer experimental

204 site (Negev Desert), our discussions were always constructive and inspiring. There is no doubt that I am

205 indebted to Dan for introducing me to the geology of Northern Israel, his advice for the choice of my 
PhD site, and his never-ending intellectual stimulation, mostly during my frequent visits in Israel in the

207 1990's. Dan Yaalon had the talent to bring out the best of yourself, a rare gift of great intellectual 208 generosity.

\section{Middle Eastern Connections - John Ryan}

211 It is both an honor and a privilege to give a few brief reflections on the life of Dan Yaalon, a colossus in

212 the field of soil science and related earth sciences. The passing of Dan in early 2014 marked a very sad

213 year for pedology as it also coincided with the deaths of two other titans of our profession, Rudi Dudal

214 and Hari Eswaran, both of whom I had known for many years.

216 I first came across the name of Dan Yaalon in the soils literature when I arrived in the Middle East to

217 take up a position of assistant professor in the Faculty of Agriculture at the American University of Beirut

218 in Beirut, Lebanon. As the only soil scientist in the Faculty, and one of the few in Lebanon, I was required

219 to address most areas in soil science in addition to my own interest of soil fertility and plant nutrition.

220 My expanded interests embraced the genesis, classification and management of the typical soils of the

221 Middle East, especially the red Mediterranean soils typical of Israel and Lebanon. Most of the published

222 research on such soils was from Israel, and it was in such reading that I encountered Dan Yaalon. It was

223 clear to me that he was a leading authority on such soils, and I was later to learn that he addressed

224 areas such as geomorphology and the history of soil science; indeed he was instrumental in promoting

225 soil history as a sub-discipline in soil science (Landa and Brevik, 2015). In recognition to these latter

226 endeavors, Warkentin (2006) made special acknowledgement of Dan Yaalon in his "Footprints in the

227 Soil". Given my proximity in Lebanon to Dan in Israel, had circumstances been normal, I would have

228 visited him. However, the sad political reality was that such a visit was not possible. Therefore, I could 
229 only hope that one day I would meet this iconic figure in soil science. Such a meeting was to occur many 230 years after my 11 years in Lebanon.

232 Having moved to Aleppo, Syria with the International Center for Agricultural Research (ICARDA), my

233 international travels were less restrictive. I recall attending a lecture by him at the World Soils Congress

234 in Montpelier in 1998--a veritable tour de force, as were all his lectures. As members of the

235 Mediterranean Soils Network, we both attended the 1999 meeting in Barcelona. There, in addition to

236 hearing him in the formal sessions and on the field tour, I had the distinct pleasure of sitting next to him

237 and his charming wife at the banquet table. It was a memorable experience, and one of those evenings

238 that one always treasures; I felt that we had known each other for years. We shared our mutual

239 experiences of living in Israel and the Arab World. Though it was not possible for him to visit the

240 surrounding countries, Dan showed a keen interest in learning about life in the Arab World, and was

241 intrigued at the fact that I was living there for so long. Being the perceptive and open-minded person

242 that he was, Dan sought to have an objective perspective and see both sides of the tragic conflict that

243 plagues the region. Dan and I were one in our hope that Shalom and Salam would prevail, and that as

244 soil scientists our work would benefit the people of the whole region. The Mediterranean Soils Meeting

245 in Bari in 2001 provided another opportunity to further our friendship.

247 I met Dan again at the World Soils Congress in Bangkok (2002), where we had an enjoyable exchange.

248 However, I was sorry to note his difficulty in walking and need for a portable seat. I met him again at the 249 subsequent ASA meeting. However, despite his health problems, Dan displayed amazing fortitude and 250 strength of character in his pursuit of his lifelong professional interest in soils. Over the years of these 251 brief encounters, I came to appreciate his intellectual depth and breadth--and his extraordinary energy. 252 Along with professional awe and respect, I developed an affection for Dan as a cultured human being. In 
253 the age of email, I was able to keep in touch with him in Israel, but not directly; I routed my emails to

254 Dan through our mutual friend Ahmet Mermut in Canada.

255

256 When Dan received the Dockuchaev Award from the IUSS, I thought it so fitting for such an outstanding

257 soil scientist who did so much for paleopedology, and indeed for championing the relevance of soil

258 science to society at large. While I was disappointed that Dan could not be present in Brisbane to accept

259 his award, I was pleased that his granddaughter did the honors for him. I would have loved to share a

260 picture with him on that occasion. However, I did write Dan to give my impression of the Award

261 ceremony and to congratulate him on this distinction. I even went further and told him of my deep

262 respect for his professional achievements and how I valued him as a role model and friend. Dan was

263 most gracious in his response, and amusingly said what I had written was something that is normally

264 penned posthumously, but admitted that he was glad to be alive to read such words. Unfortunately, I

265 was never able to visit him in Israel or see him again. Shortly, my own world was to collapse, and the

266 region engulfed in a downward spiral of conflict and tragedy. I take inspiration from Dan Yaalon in not

267 losing hope in a better tomorrow no matter how bad things are today. Despite the vicissitudes and

268 trauma of his life, Dan Yaalon never gave up.

270 I was delighted to honor the memory of Dan Yaalon by attending the Memorial Symposium in Vienna. It

271 brought home to me how uniquely privileged I was to know such a great soil scientist and a sterling

272 human being who is an inspiration for all of us.

273

274

\section{A Connection Between Mediterranean Pedologists - Rosa M. Poch}

275 As a soil scientist working mainly on soils formed under a Mediterranean climate, I have invariably been 276 in contact with Dan Yaalon's works since the beginning of my scientific career. In addition, my focus has 
277 been the study of soil genesis using mainly micromorphology, and I must admit that reading Yaalon's

278 papers has been extremely useful for understanding how my soils formed and behaved, in spite of being

279 at the opposite side of the Mediterranean.

281 Gypsiferous soils were the subject of my PhD in 1992. Some years after I was pleased to read Yaalon's

282 findings about displacive crystallization of gypsum in desert soils (Amit et al., 1993; Amit and Yaalon,

283 1996). Afterwards, my research on calcareous soils and paleosoils, mainly with recarbonated argillic

284 horizons, was very much clarified by the excellent paper on Mediterranean Soils (Yaalon, 1997) and by

285 his works with Moshe Wieder (Wieder and Yaalon 1974; 1982). In the last few years I discovered

286 Mediterranean loess, and again I found very explanatory papers on desert loess and its characteristics

287 that make it distinct from "temperate" loess in Yaalon (1969), Yaalon and Ganor (1973), Yaalon and Dan

288 (1974) and Yaalon (1987). Therefore, in spite of the fact that I never met Dan Yaalon, I have been and

289 continue to be helped and supported by him when studying the soils of my natural environment.

\section{Soil Geomorphology in Israel - Onn Crouvi}

292 When I started my undergraduate studies in the Institute of Earth Sciences at The Hebrew University of

293 Jerusalem in 1995, Dan Yaalon had already been retired for several years. Thus, I never had the

294 opportunity to take one of his classes. I would see Dan at the Institute library as he was browsing

295 through the latest journal volumes, and it impressed me that a retired professor was so eager to stay on 296 top of the latest research developments.

298 I developed a more personal connection with Dan about a year later. During a geological mapping 299 course that was held in the Judean Mountains, each group of 2-3 students conducted a small research 300 project based on the groups' field findings. My colleagues and I chose to work on 'Nari', the calcrete 
301 mantling chalk-rich formations in the mapping area. Naturally, Dan was our advisor for this project, since

302 he had studied the development of calcretes during the 1970s. Although he did not join us in the field, I

303 remember the many intellectually inspiring, yet demanding research discussions I had with him. Dan's

304 guidance really played a critical role in my first independent research experience, having a profound

305 influence on the direction of my career.

306

307 In 2001, Dan received an Honor medal from the Israel Geological Society for his remarkable

308 contributions to surficial geology and geomorphology; it was not trivial for a pedologist to receive a

309 medal from the geological community. The award was presented by Rivka Amit (then president of the

310 society, as well as one of Dan's academic successors in soil-geomorphology research) during the

311 society's annual meeting. In his acceptance speech, Dan gave a short overview of his career,

312 highlighting important aspects of his achievements. As a young M.Sc. student in the field of soil-

313 geomorphology, I listened carefully to his speech. One segment that left an unforgettable imprint on my

314 memory was his recounting of how, in the 1960's and '70's, leading members of the scientific

315 community opposed his findings that loess can be formed through non-glacial processes, and that dust

316 contributed significantly to the development of soils in the Middle East. It is worth mentioning that

317 these conclusions have since been corroborated by numerous studies and now represent the consensus

318 opinion. In his speech, Dan was specifically addressing the students in the audience, stressing the

319 importance of standing behind one's conclusions, even if contradictory to the leading paradigm. This

320 message was particularly apropos when, during my closely-related doctoral research, I reached a

321 conclusion not in alignment with conventional thinking. I concluded that the major sources of desert

322 loess worldwide are the adjacent, upwind sand dunes, from which silt grains were produced by eolian

323 abrasion of sand grains. 
325 The last time I met Dan was in 2008, when he attended my Ph.D. defense presentation at the Institute of

326 Earth Sciences. I felt honored by his presence, because at that time he rarely visited the University due

327 to his difficulty walking. It seemed that he was very pleased to see that the field of soil-geomorphology

328 had become so active at Israeli universities and research institutes, where his legacy remains to this day.

\section{Great Character and Inspiring Thinker - Daniela Sauer}

331 When I think about Dan Yaalon, two characteristics of him, great character and inspiring thinker,

332 spontaneously come to mind. We never met personally, but he continuously followed the activities of

333 the IUSS Commission on Palaeopedology through the Palaeopedology Google Group and e-mail, and

334 since I became the Chair of the Palaeopedology Commission in 2010, he always supported me in my

335 work for the Commission. He never missed a chance to send his warmest regards to me through his last

336 PhD student, Danny Itkin, when he knew that Danny would see me. I feel particularly grateful for his

337 honest, steady support and his heartiness because I know what incredible evil Dan Yaalon and his family

338 had experienced from Germans in his young life. He was able not to project these experiences on the

339 next generations, not only by rationality but also by heart.

341 Secondly, of course, Dan Yaalon definitely inspired me - like numerous others - in my thinking and ideas

342 about soil formation. I have been working a lot on soil formation, studying soil chronosequences in

343 various regions of the world. Especially, in the last years, I felt more and more that soil chronosequence

344 data are often interpreted in a too straight-forward way, and that we need to consider more carefully

345 existing pedological concepts - and develop them further (Sauer, 2015). Dan Yaalon had pointed out

346 already in 1975 that any functional relationships "must be consistent with or related to the existing body

347 of scientific laws" (Yaalon, 1975). Although this point seems to be self-evident, it is not always taken into 
348 account when soil formation over time is described by fitting soil chronofunctions to the observed

349 changes.

351 Other basic concepts of Dan Yaalon that were most influential to me include:

352 - Yaalon's categorisation of soil properties according to the time-span required for their adjustment to 353 the actual environment into (i) rapidly adjusting, (ii) slowly adjusting, and (iii) persistent soil 354 properties (Yaalon, 1971);

355 - feedback systems in soil formation: Yaalon (1983) among others pointed to the existence of feedback 356 systems in soil formation, which slowly change internal processes with time;

357 the polygenetic character of most soils as discussed by Richter and Yaalon (2012);

358 - characteristics of Mediterranean soils and the role of dust (Yaalon and Ganor, 1973; Yaalon, 1987, 359 1997).

360 These concepts all have fundamental implications for studying both soil chronosequences and 361 palaeosols.

\section{The Mentor I Never Met - Jaroslaw Waroszewski}

364 In 2011 I was finishing my PhD thesis and just a few months before my public defense I realized that my 365 first important scientific project was ending and I should start looking for a new subject. I asked myself 366 where and what kind of challenging topic I should look for? One part of the answer came with the WRB 367 Workshop and Excursion that took place in Poland (2011). I was involved in the organization of the field 368 trip. During the preparation of soil profiles we evidenced silt-rich mantles, with different thicknesses, 369 over granite and serpentinite saprolites. Also later on, when I worked together with geologists (Jakub

370 Kierczak and Artur Pędziwiatr) from the University of Wroclaw on the mobility of $\mathrm{Cr}$ and $\mathrm{Ni}$ in serpentine 371 soils, I noted a similar configuration of silt material and residuum substrates. These profiles revealed a 
372 distinct record of the influence of past aeolian activity on the soils of Lower Silesia. In our discussions my

373 former supervisor (Cezary Kabała) encouraged me to go a few steps further and develop a scientific

374 project based on such examples. However, neither the stratigraphy of loess nor dust input to soils were

375 my main scientific interests during my master's and PhD studies. I did not have an overall concept of

376 how to collate all the examined soil profiles and prepare a proposal.

378 A breakthrough came when I found three publications written by Dan Yaalon (Yaalon and Ganor, 1973;

379 Yaalon, 1975; Yaalon, 1987). These helped me to better understand the role of aeolian silt sediments in

380 soil formation. The earliest of these articles, related to the evaluation of the influence of dust on soils

381 (Yaalon and Ganor, 1973), turned out to be the most important. This paper shows the conceptual model

382 of a soil continuum that displaces different stages of aeolian influence and fits very well with the

383 pedological situation of the Silesia region - this is it, I thought, as I started working on the project! In the

384 following months I built a hypothetical model for aeolian silt influenced soils in Lower Silesia. Of course, I

385 realize that many other scientists have been inspired by Dan Yaalon's publications and the ideas they

386 contain, e.g. Karathanasis and Macneal (1994) and Muhs et al. (2010). However, in my case this

387 inspiration was twofold: first of all, the dust-soil continuum presented by Yaalon changed my general

388 view on the impact of aeolian silt on soils; and second, the articles helped me ultimately choose my

389 main field of study and its objectives.

391 Eventually, I wrote a proposal inspired by Dan Yaalon's publication, entitled "Verification of parent

392 material homogeneity in soils developed from crystalline and sedimentary rocks in the loess-influenced

393 territory of the Lower Silesia region". This project was successfully accepted for funding by the National

394 Science Center in Poland and has become my habilitation grant. Over the next three years, I will try to

395 determine: (1) the criteria for allochtonous and residual materials differentiation in geologically variable 
environments; (2) the age and duration of the formation of subsequent soil genetic horizons/layers; (3)

397 the stratigraphic markers for spatial distinction of aeolian and non-aeolian substrates; and (4) the 398 approximate southern margin of aeolian silt input recorded in soils of south-western Poland.

400 Unfortunately, I never had a chance to meet Dan Yaalon in person. Yet, my work on the subject of

401 aeolian input in soils and expanding knowledge regarding the soils of Lower Silesia is surely the best way

402 to thank him for his remarkable inspiration!

\section{A Touch of Knowledge - Elizabeth Solleiro}

405 Since I began my studies of soil genesis, I have read Dan Yaalon's papers. I liked the way he 406 communicated, as he was able to translate in simple words the complex models of pedogenetic 407 processes. I met Dan Yaalon during the World Congress of Soil Science held in Mexico, in 1994. I was 408 studying my PhD, working on paleopedology. We had no specialists in this research area in Mexico.

409 Thus, I attended the conference and went to a session organized by Dan. I was very impressed with his 410 personality. When the session finished, I approached him and asked for some recommendations in my 411 research project. With a big smile, he talked to me, recommended some papers, and gave some advice 412 to use paleosols as a proxy for the paleoenvironmental reconstruction. I was touched by his words 413 pushing me to go farther, in a topic that was then completely new in Mexico.

415 Some years later, in 2003, I started to work with soils developed on limestones in Yucatan, in a karstic 416 environment. The complexity of soil distribution, going from the thin black Rendzinas, to outcrops of 417 limestone, to soils and pedosediments inside karstic pockets, and finally to the thick, red, clayey soils, 418 made me search for the classic works on Terra Rossa. That was when I read Yaalon's papers on Red 
419 Mediterranean Soils (Yaalon, 1987; 1997). Once again, I was touched by the ideas he proposed, which

420 were used partially to explain the genesis of soils in Yucatan.

421

422 Although my relationship with Dan Yaalon was short, the knowledge and inspiration he transmitted to

423 me was very stimulating in my scientific career.

\section{A Scientist That Kept Working - Curtis Monger}

426 Dan Yaalon's influence on my career began when I was a graduate student at New Mexico State

427 University in the mid-1980s. He was a member of the International Commission on Aridisols (ICOMID)

428 group that came to Las Cruces, New Mexico in 1987 to tour the Desert Soil-Geomorphology Project on

429 their way across the arid southwest from Texas to California (Figure 3).

431 The following summer I attended the 1988 IUSS Micromorphology meeting in San Antonio hosted by

432 Larry Wilding and his colleagues at Texas A\&M University. Dan Yaalon was an outspoken leader at that

433 meeting, including the debate about whether micromorphology is a science or a technique. Dan argued

434 persuasively that it's both. One day I got up enough nerve to join him in the walk between the cafeteria

435 and the auditorium and brought up the topic of dust as a source of pedogenic carbonate. He, of course,

436 was a strong advocate of the dust hypothesis, which would become fundamental for explaining

437 carbonates in the Southwestern USA. Lee Gile had long viewed Yaalon as an ally on this subject. From a

438 micromorphology point of view, the paper by Wieder and Yaalon (1974) was important for my research

439 because it clearly laid out the logic for understanding whether a nodule had formed in situ or was

440 detrital based on its silicate mineralogy. 
442 I saw Dan later that year at the SSSA Meeting in Anaheim where he was an invited speaker on pedogenic

443 carbonates. He said that previously he did not think microorganisms precipitated pedogenic carbonate,

444 but given recent evidence in Spain, he had changed his mind. To me, a graduate student, that was very

445 influential, and I now think the ability to change one's mind in light of new evidence is the signature of a

446 great scientist. Also from his presentation I got the idea to conduct a lab experiment to determine if

447 microorganisms in New Mexico soils could precipitate pedogenic carbonate-they did (Monger et al.

448 1991).

450 In 1993, now an assistant professor, I attended a Paleosol symposium hosted by Leon Follmer and Don

451 Johnson at the Allerton House, University of Illinois. Dan wasn't the elder statesman at that meeting

452 because Roger Morrison was there, but he was a close second. The major debate at this meeting was

453 how deep and how old does a buried soil have to be before it can be considered a paleosol? And what if

454 an ancient soil was never buried? Dan's concepts in Yaalon (1971) of "slowly adjusting" and "reversible

455 properties" provided a framework for this debate (both relict and buried paleosols). Still, no consensus

456 was reached.

457

458 The next time I saw Dan was at the Argentinian Soil Science Society in Santa Rosa in 1996. During my talk

459 I showed a thin section followed by a satellite image. Dan told me afterwards that I had lost the

460 audience by making such a leap in scale. I wouldn't have known that if he hadn't bothered to tell me.

462 Carbon sequestration had become a hot topic by 1997 when I next saw Dan at the "Pedogenic

463 Carbonate and Global Climate Change" conference in Tunisia organized by Rattan Lal, John Kimble, and

464 their Tunisian colleagues. The field trips were excellent. I particularly remember how honored and

465 carefully a couple of Muslim graduate students helped Dan into and out of soil pits on a steep slope. 
467 Although I corresponded thru email with Dan until February 2013, the last time I saw him was in 2002 at 468 the World Congress of Soil Science in Thailand. Riding in a cab from the hotel to the conference I asked 469 Dan how he had managed to accomplish so much. He said: "I just kept working."

\section{No Soils for Geologists - Franz Ottner}

472 Unfortunately I never met Dan Yaalon personally, but quite early I realized there was a great elderly man

473 in Israel who published a lot of interesting papers on soils, and for me was influential for drawing

474 together geology and soils.

476 During my studies of geology at the University of Vienna no lecture about soils or paleosols existed in

477 the entire curriculum. Generations of geologists were involved in solving the secrets of genesis and 478 structure of the Alps. There were intense discussions about the rocks down to 30,000 meters depth, but 479 the uppermost meter of the more or less altered rock was not of interest. However, the history of 480 geology and mineralogy was of great interest, so I came across Dan Yaalon because of his work on the 481 history of soils.

483 The situation changed when I started my PhD work at BOKU. The main topic was the mineralogy of clays 484 for engineering use. The gap between geology, clays, and soil became small, and soil mineralogy was of 485 great interest.

487 Studying the stratigraphy and sedimentology of Austria and the surrounding countries, very often I 488 found indications of former landscapes. Therefore my first paleosols were found or recognized and from 
this time on paleopedology played a major role in my research. To explore paleopedology means to get

490 in contact with the work of Gregory Retallack and Dan Yaalon.

491

492 Most clays and soils contain a lot of iron oxides and hydroxides and soon I had the opportunity to meet

493 with Arieh Singer from Israel. I got a personal copy of his book "The Soils of Israel" and of course I came

494 again across Dan Yaalon's work.

496 For my future scientific work and teaching of Earth sciences, the Dan Yaalon Symposium provided an

497 essential impact. The personal contact with Yaalon's family, friends and colleagues was highly

498 impressive. Particularly during the visit to Dan Yaalon's birthplace, Uherske Hradiste, I could feel the 499 spirit of the great scientist and human being, who influenced my scientific work so significantly. It is my

500 ambition to change the rule in Austria from "no soils for geologists" to "soils are an important and 501 exciting part of geology".

13. Dan Yaalon - an outstanding pedologist developing Dokuchaev's paradigm - Victor Targulian

504 The first time I heard Yaalon's name was in the 1970s when I read his famous article "Soil-forming

505 processes in time and space" published in the book "Paleopedology" (Yaalon, 1971), based on his talk at

506 the first conference of paleopedology in Amsterdam. This article impressed me very much because of its

507 close adjacency to the Russian approach to the problem of soil behavior in time and space. I thought of

508 him as a "friend of spirit" in this problem.

510 I met Dan personally, face-to-face at the World Soil Science Congress in Edmonton, Canada, in 1978

511 where he gave me a great compliment while speaking to a small party of Canadian soil scientists. "A-ha,

512 this is the young Russian soil science star" he exclaimed playfully. He mentioned the publication of my 
513 book "Soil Formation and Weathering in Cold Humid Areas" (Targulian, 1971). I was simultaneously

514 strongly confused and very proud by these words: Dan was ten years older than me and had already

515 achieved wide recognition as a pedologist.

516

517 From this time I started to read many of Dan's articles and widely promoted his work among my Russian

518 colleagues. It was not easy: it was the time of the Cold War and there were no diplomatic relations

519 between the USSR and Israel. However, we met many times at World Soil Congresses: in Germany,

520 Japan, Thailand, Mexico, France, etc. Fortunately, after "perestroika” our Russian Dokuchaev Soil

521 Science Society had a chance to invite Dan to visit Russia to participate in some international

522 conferences and once even in the USSR National Soil Science Congress, where he was elected as an

523 Honorary Member of the Russian Soil Science Society.

524

525 Dan's work, and in particular, his evolutionary concepts of soil development, his approach to the

526 assessment of fast and slow soil processes interaction during pedogenesis, and his enthusiastic

527 propagation of the paleopedological approach to the understanding and use of present-day exposed

528 contemporary soils very deeply affected pedology and paleopedology both in Russia and throughout the

529 entire world. Dan Yaalon's creative work is one of the best examples of the profound impact of the

530 genetic Dokuchaev-Jenny pedological approach and will help scientists worldwide better understand soil

531 genesis and to better forecast soil behavior in the future.

532

14. Conclusions

534 Dan Yaalon was a major advocate for the study and documentation of the history, philosophy, and 535 sociology of our field (Landa and Brevik, 2015). Dan once told E. Brevik "History is made by people - not 536 anonymous efforts or events" (written communication, 19 August 2011). Dan's point was that it is 
537 important for us to document the accomplishments of individuals who have done the work that

538 advances science and not only the scientific advance itself; without the people, there are no advances.

539 This was a principle that Dan firmly adhered to.

541 In this paper several individuals have told how Dan influenced them, something that was a major

542 accomplishment of Dan's. In some cases that accomplishment took place within a close working

543 relationship, physically being in the classroom, field, or laboratory with Dan. In other cases that

544 influence came mainly through periodic contact at professional meetings or by correspondence, either

545 postal mail or email (Figure 4). And in still other cases it was indirect, through Dan's writings without

546 direct interaction. This influence took place across multiple generations of scientists, including those

547 who today are retired, in mid-career, and just beginning their careers. But in all cases Dan, the

548 individual, touched each of us and, hopefully, helped sustain us in our contributions to our various fields

549 of study, demonstrating that a successful scientist makes significant contributions to their fields not only

550 through their papers and books but also through their influence on others. It is the hope of the authors

551 of this paper that Dan would have appreciated and been proud of the effort made here to document

552 individual accomplishments through personal impacts of one of the people who made major

553 contributions to the science of his day.

\section{Acknowledgements}

556 The authors wish to acknowledge the influence of Dan H. Yaalon in each of their subfields and on each

557 of them personally. We thank Danny Itkin and an anonymous reviewer for their comments and

558 suggestions that improved the final paper.

\section{References}


Amit, R., Yaalon, D.H., 1996. The micromorphology of gypsum and halite in reg soils-the Negev Desert, Israel. Earth Surf. Proc. Land. 21(12), 1127-1143.

Amit, R., Gerson, R., Yaalon, D.H., 1993. Stages and rate of the gravel shattering process by salts in desert Reg soils. Geoderma 57(3), 295-324.

Brevik, E.C., 1999. George Nelson Coffey: Early American pedologist. Soil Sci. Soc. Am. J. 63(6), 14851493.

Brevik, E.C., 2004. Contributions of Edward Elway Free to American soil science in the early 1900s. Soil Sci. Soc. Am. J. 68, 904-906.

Brevik, E.C., Burgess, L.C. (Eds.), 2013. Soils and human health. CRC Press, Boca Raton, FL.

Brevik, E.C., Cerdà, A., Mataix-Solera, J., Pereg, L., Quinton, J.N., Six, J., Van Oost, K., 2015a. The interdisciplinary nature of SOIL. SOIL 1, 117-129. doi:10.5194/soil-1-117-2015

Brevik, E.C., Calzolari, C., Miller, B.A., Pereira, P., Kabala, C., Baumgarten, A., Jordán, A., 2015b. Soil mapping, classification, and modeling: history and future directions. Geoderma. doi:10.1016/j.geoderma.2015.05.017.

Brevik, E.C., Fenton, T.E., Homburg, J.A., 2015c. Historical highlights in American soil science - prehistory to the 1970s. Catena. doi:10.1016/j.catena.2015.10.003

Cline, M.G., 1961. The changing model of soil. Soil Sci. Soc. Am. Proc. 25(6), 442-446. doi:10.2136/sssaj1961.03615995002500060009x

Finck, A., 2014. In memoriam Dan Yaalon. https://danyaalonsymp.unihohenheim.de/uploads/media/In Memoriam Letter by Arnold Finck.pdf. Accessed 4 July 2015.

Itkin, D., 2014. Dan (Hardy) Yaalon, pedologist and soil scientist, 1924-2014. Earth Sciences History 33(1), 176-178.

Karathanasis, A.D., MacNeal, B.R., 1994. Evaluation of parent material uniformity criteria in loessinfluenced soils of west-central Kentucky. Geoderma 64, 73-92.

Landa, E.R., Brevik, E.C., 2015. Soil science and its interface with the history of geology community. Earth Sciences History 34(2), 296-309.

Monger, H.C., Daugherty, L.A., Lindemann, W.C., Liddell, C.M., 1991. Microbial precipitation of pedogenic calcite. Geology 19, 997-1000.

Muhs D.R., Budahn J.R., Johnson D.L., Reheis M., Beann J., Skipp G., Fisher E., Jones J.A., 2010. Geochemical evidence of airborne dust additions to soils in Channel Islands National Park, California. Geol. Soc. Am. Bull. 120(1/2), 106-126.

Richter, D., Bacon, A.R., Megan, L.M., Richardson, C.J., Andrews, S.S., West, L., Wills, S., Billings, S., Cambardella, C.A., Cavallaro, N., DeMeester, J.E., Franzluebbers, A.J., Grandy, A.S., Grunwald, S., Gruver, 
J., Hartshorn, A.S., Janzen, H., Kramer, M.G., Ladha, J.K., Lajtha, K., Liles, G.C., Markewitz, D., Megonigal, 610 P.J., Mermut, A.R., Rasmussen, C., Robinson, D.A., Smith, P., Stiles, C.A., Tate, R.L., Thompson, A., Tugel, 611 A.J., van Es, H., Yaalon, D., Zobeck, T.M., 2011. Human-soil relations are changing rapidly: Proposals 612 from SSSA's cross-divisional soil change working group. Soil Sci. Soc. Am. J. 75(6), 2079-2084.

613 doi:10.2136/sssaj2011.0124

614

615

Richter, D., Yaalon, D.H., 2012. "The changing model of soil” revisited. Soil Sci. Soc. Am. J. 76(3), 766778. doi:10.2136/sssaj2011.0407

Richter, D., Landa, E.R., Brevik, E., Berkowicz, S., 2014. In memoriam: Dan Hardy Yaalon 1924-2014. Catena 123, 272-273.

Rohdenburg, M., 2014. Last honours to Dan H. Yaalon. Catena 123, 270-271.

Sauer, D., 2015. Pedological concepts to be considered in soil chronosequence studies. Soil Research 53(6), in press.

Targulian, V.O., 1971. Soil formation and weathering in cold humid regions: (on Massive-Crystalline and Sandy Polymictic rocks). Nauka, Moscow. (in Russian).

Verrecchia, E.P., Dumont, J.L., 1996. A biogeochemical model for chalk alteration by fungi in semiarid environments. Biogeochemistry 35(3), 447-470.

Warkentin, B.P. (Ed.), 2006. Footprints in the soil: People and ideas in soil history. Elsevier, Amsterdam.

Wieder, M., Yaalon, D.H., 1974. Effect of matrix composition on carbonate nodule crystallization. Geoderma 11(2), 95-121.

Wieder, M., Yaalon, D.H., 1982. Micromorphological fabrics and developmental stages of carbonate nobular forms related to soil characteristics. Geoderma 28(3), 203-220.

Yaalon, D.H., 1969. Origin of desert loess. In: Etudes sur le Quaternaire dans le Monde. Bulletin de l'Association Francaise pour l'Etude du Quaternaire, vol. 2. Association Francaise pour l'Etude du Quaternaire (AFEQ), Paris, France, p. 755.

Yaalon, D.H., 1971. Soil forming processes in time and space. In: Yaalon, D.H. (Ed.), Paleopedologyorigin, nature and dating of paleosols. Int. Soc. Soil Sci. and Israel Univ. Press, Jerusalem, pp. 29-39.

Yaalon, D.H., 1975. Conceptual models in pedogenesis. Can soil-forming functions be solved? Geoderma $14,189-205$.

Yaalon, D.H., 1983. Climate, time and soil development. In: Wilding, L.P., Smeck, N.E., Hall, G.F. (Eds.), Pedogenesis and Soil Taxonomy: I. Concepts and Interactions. Elsevier, NY, pp. 233-251.

Yaalon, D.H., 1987. Saharan dust and desert loess: effect on surrounding soils. J. Afr. Earth Sci. 6(4), 569571. 
656 Yaalon, D.H., 1997. Soils in the Mediterranean region: what makes them different? Catena 28(3), 157-

657169.

658

659 Yaalon, D.H., 2000. Soil care attitudes and strategies of land use through human history. Sartoniana 13, 660 147-159.

661

662 Yaalon, D.H., 2012. The Yaalon story; a passion for science and Zion. Maor Wallach Press, Jerusalem.

663

664 Yaalon, D.H., Dan, J., 1974. Accumulation and distribution of loess-derived deposits in the semi-desert 665 and desert fringe areas of Israel. Z. Geomorphol. Supp. 20, 91-105.

666

667

668

Yaalon, D.H., Ganor, E., 1973. The influence of dust on soils during the Quaternary. Soil Sci. 116, 146-

669

670

671

672

673

674

675

676

677

678

679

680

681

682

683

684

685

686

687

688

689

690

691

692

693

694

695

696

697

698

699

700

701

702

703

Yaalon, D.H., Yaron, B., 1966. Framework for man-made soil changes-an outline of metapedogenesis. Soil Sci. 102(4), 272-277. 
704

705

706

707

708

709

710

711

712

713

714

715

716

717

718

719

720

721

722

723

724

725

726

727

728

729

730

731

732

733

734

735

736

\section{Figure Captions}

Figure 1. Dan H. Yaalon (left) and Yaalon holding a picture of himself as a child (right). Left photograph courtesy of Uri Yaalon, right photograph courtesy of Rachael Cerrotti (http://www.rachaelcerrotti.com).

Figure 2. Dan Yaalon describing a paleosol. Photo courtesy of Danny Itkin.

Figure 3. Members of the International Commission on Aridisols (ICOMID) at the Upper Las Mesa site near Las Cruces, New Mexico in 1987. From left to right: Larry Wilding, Dan Yaalon, Leland Gile, René Tavernier, Bill Johnson, Wim Sombroek, and B.L. Allen. Photo courtesy of Curtis Monger.

Figure 4. Even after retirement, Dan Yaalon worked from his home office to keep up with the latest developments in his fields of interest, publish papers, and maintain contacts with other scientists from around the world. Photo courtesy of Uri Yaalon. 

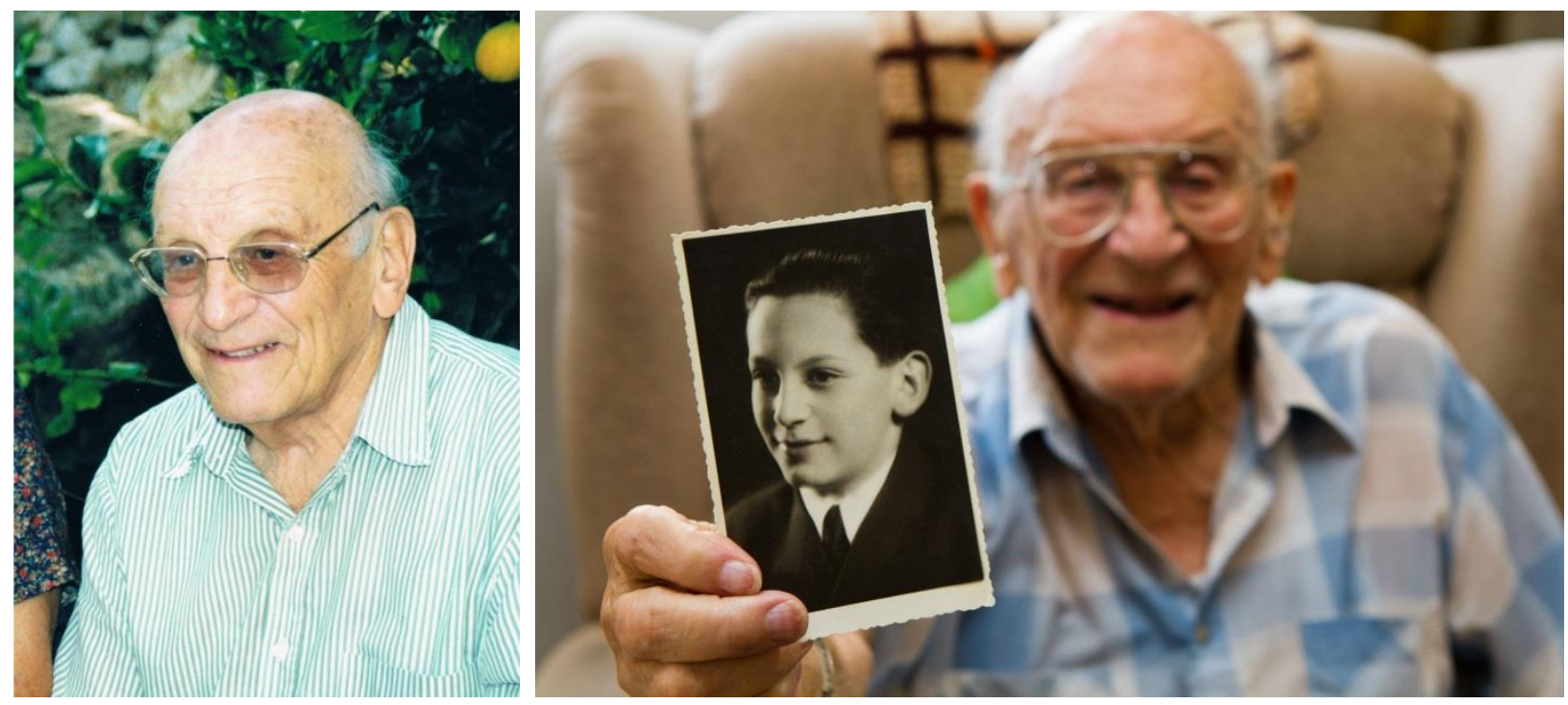

Figure 1. Dan H. Yaalon (left) and Yaalon holding a picture of himself as a child (right). Left photograph courtesy of Uri Yaalon, right photograph courtesy of Rachael Cerrotti (http://www.rachaelcerrotti.com). 


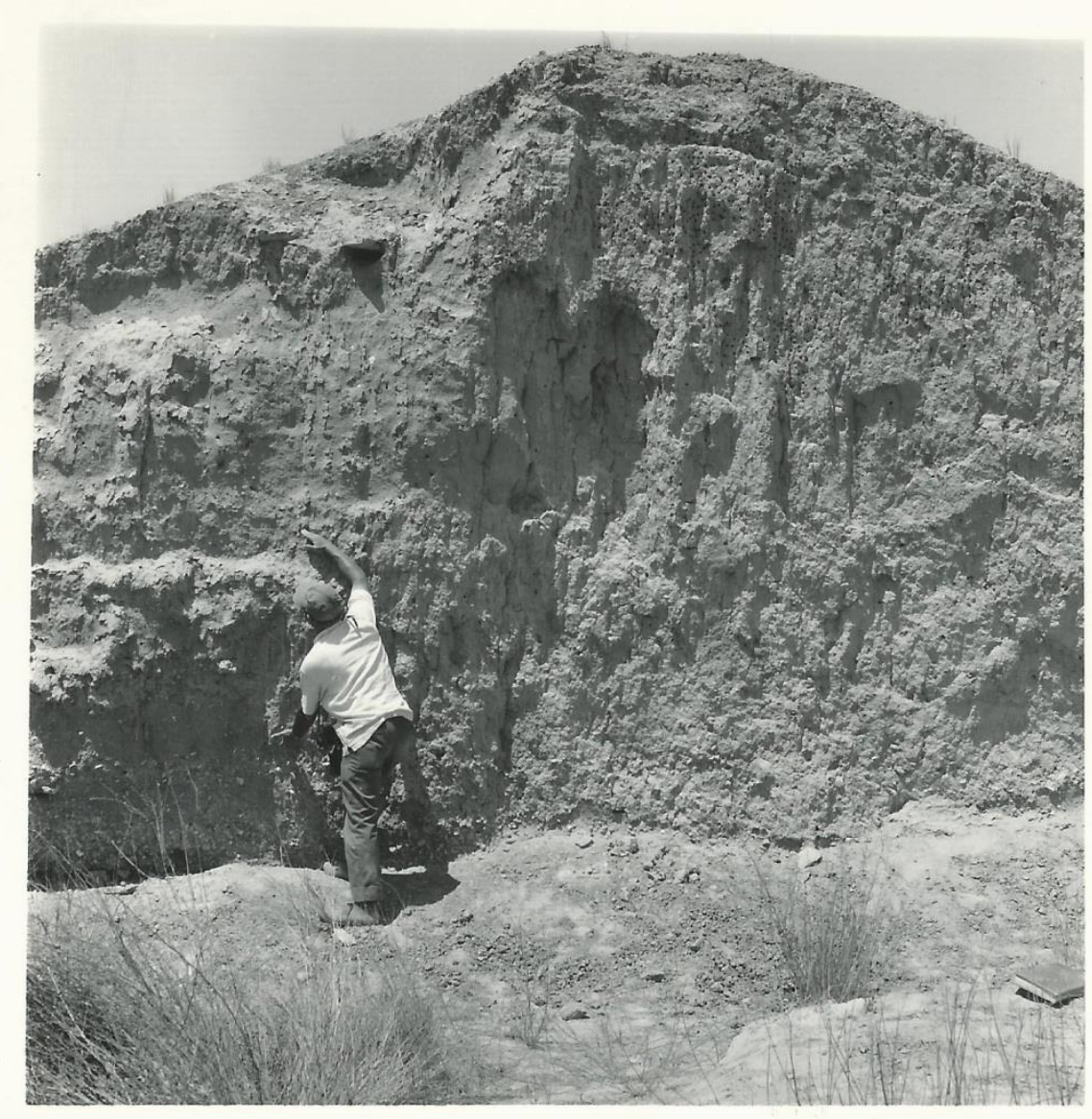

748 Figure 2. Dan Yaalon describing a paleosol. Photo courtesy of Danny Itkin.

749

750

751

752

753

754

755

756

757

758

759

760

761

762 


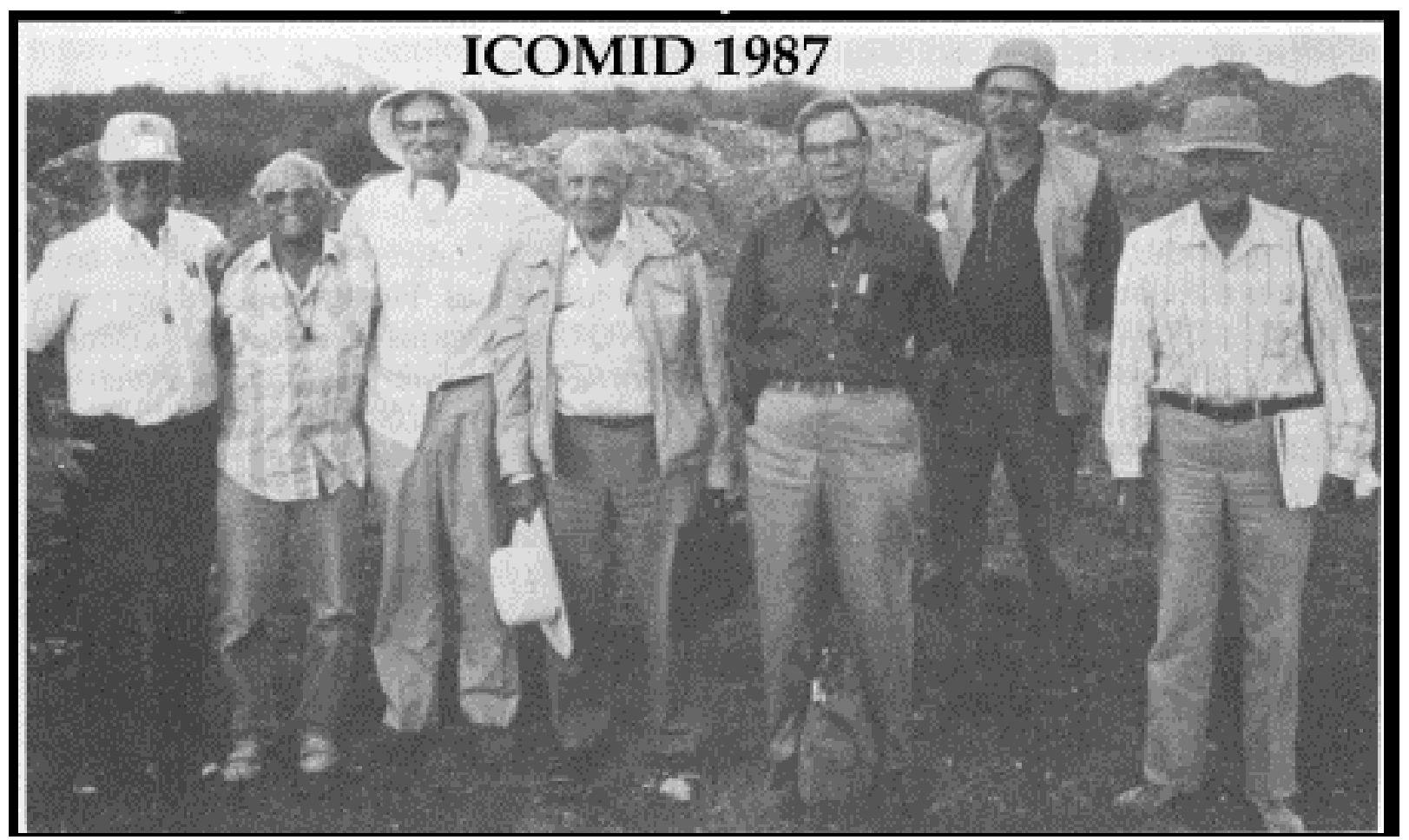

Figure 3. Members of the International Commission on Aridisols (ICOMID) at the Upper Las Mesa site near Las Cruces, New Mexico in 1987. From left to right: Larry Wilding, Dan Yaalon, Leland Gile, René Tavernier, Bill Johnson, Wim Sombroek, and B.L. Allen. Photo courtesy of Curtis Monger. 


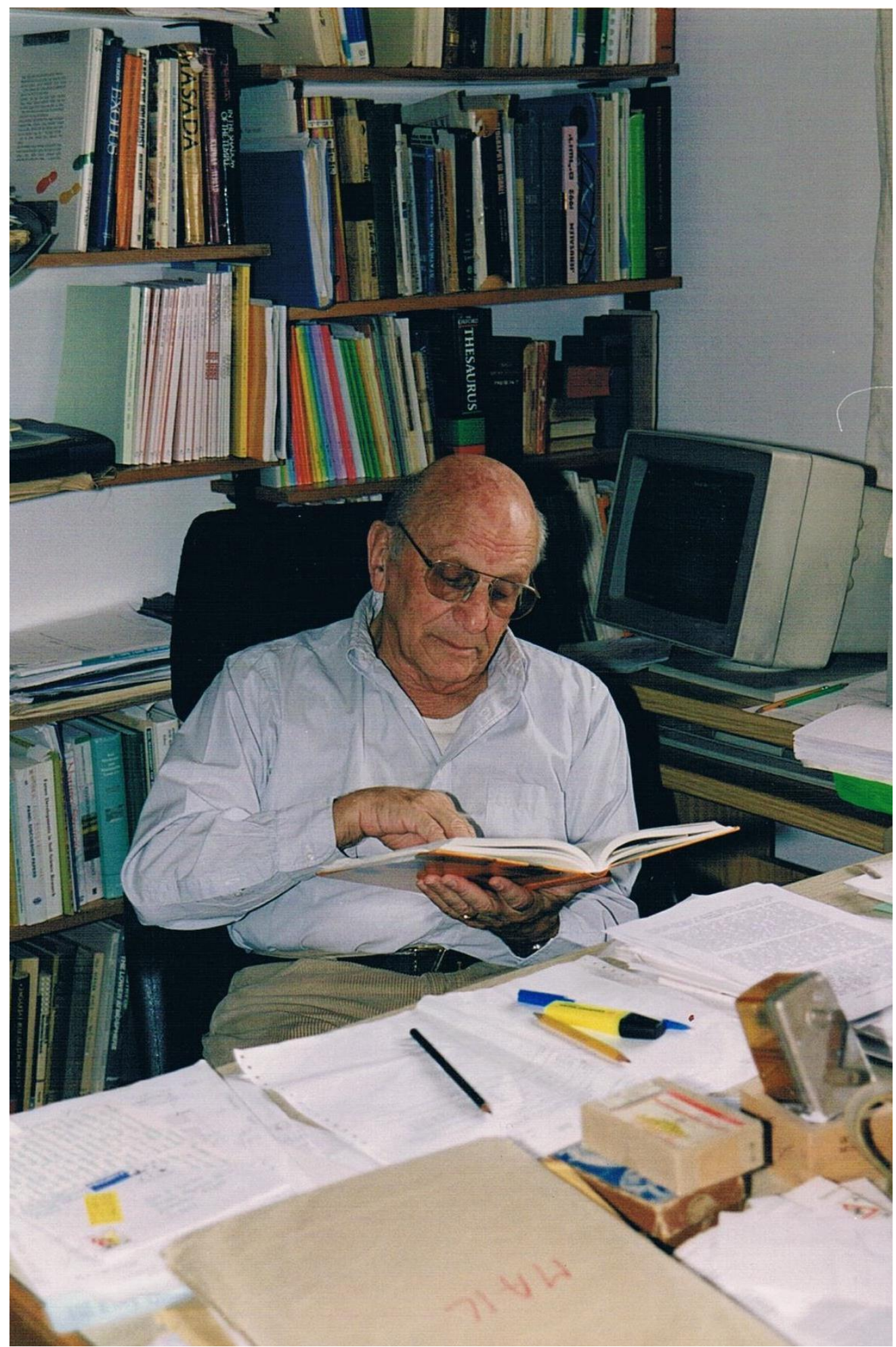

Figure 4. Even after retirement, Dan Yaalon worked from his home office to keep up with the latest developments in his fields of interest, publish papers, and maintain contacts with other scientists from 771 around the world. Photo courtesy of Uri Yaalon. 